\title{
A case study of learning strategies of older adults attending an English course
}

\author{
Juan F. Mora' ${ }^{1}$, Isabel R. Quito ${ }^{1}$ (D), Louis E. Macías ${ }^{1}$ (D), María I. Fárez ${ }^{2}$ (D), \\ María E. Quinde ${ }^{2}$ iD \\ 1 Instituto Universitario de Lenguas, Universidad de Cuenca, Av. 12 de abril, Cuenca, Ecuador. \\ 2 GIER, Universidad de Cuenca, Av. 12 de abril, Cuenca, Ecuador. \\ Autor para correspondencia: fernando.mora@ucuenca.edu.ec \\ Fecha de recepción: 6 de noviembre de 2018 - Fecha de aceptación: 11 de noviembre de 2018
}

\begin{abstract}
This study explores the most frequently used learning strategies of a group of older adults in the city of Cuenca, Ecuador, attending an English course. Sixty-six participants (with an average age of 71.05) responded to the 50-item questionnaire on learning strategies of Oxford (1990). Statistical analyses and an analysis of correlation between sociodemographic variables were conducted to determine the prevailing learning styles of the intervention group and its relationship with the sociodemographic characteristics of the participants. The results indicate that older adults use all the strategies categorized by Oxford, predominantly the metacognitive ones, meaning that they mainly reflect, plan, monitor, and evaluate their own learning process. In addition, the results reveal the positive correlation of the variables age, level of English, and level of education and occupation before retirement. The three last-mentioned were found to be determinant in the preferences of the participants.
\end{abstract}

Keywords: Older adults, learning strategies, lifelong learning, EFL.

\section{RESUMEN}

Este estudio examina las estrategias de aprendizaje más utilizadas por un grupo de adultos mayores en la ciudad de Cuenca, Ecuador. Sesenta y seis participantes (con una edad promedio de 71.05) que tomaron un curso de inglés como lengua extranjera respondieron al cuestionario de 50 preguntas sobre estrategias de aprendizaje de Oxford (1990). Se realizaron análisis estadísticos y un análisis de correlación entre las variables sociodemográficas para determinar los estilos de aprendizaje prevalecientes del grupo de intervención y su relación con las características sociodemográficas de los participantes. Los resultados indican que los adultos mayores utilizan todas las estrategias categorizadas por Oxford, de manera particular las metacognitivas, lo que significa que principalmente reflexionan, planifican, monitorean y evalúan su propio proceso de aprendizaje. Además, los resultados revelan la correlación positiva de las variables edad, nivel de inglés y nivel de educación y ocupación antes de la jubilación. Se evidenció que las tres últimas fueron determinantes en las preferencias de los participantes.

Palabras clave: Adultos mayores, estrategias de aprendizaje, aprendizaje permanente, EFL.

\section{INTRODUCTION}

The study of learning strategies has been widely reported, particularly regarding the benefits of using them in an academic setting. It is important to start by providing a definition of learning strategies. A pertinent definition is that of Dansereau (1985), who conceives them as "a set of processes or steps which might facilitate the acquisition, storage and use of information". Another important definition is provided by Monereo (1994), who states that learning strategies are "planned behaviors which select and organize cognitive, affective, and motor mechanisms in order to cope with global or specific learning situations". On the other hand, some consider the expression learning strategies to be a synonym of the terms learning behaviors, tactics, resources, skills, and others (Griffiths, 2008), while others regard them as different (Gómez, 2013), stating that learning techniques are specific activities students use mechanically, whereas learning strategies are the reflective use of those techniques. In the field of foreign languages, Rebecca Oxford, a very well-known researcher in learning strategies, points out that such terms can be defined as "specific actions taken by the learner to make learning easier, faster, more enjoyable, more self-directed, more effective, and more transferable to new situations" (Oxford, 1990). This definition is the one that informs the development of this study.

Among the benefits of learning strategies, some studies suggested that their frequent, varied, and efficient use might result in an improvement of the students' performance in general terms (Zimmerman \& Pons, 1986; Pressley \& Associates, 1990; Barca, Peralbo, Porto, Barca, Santorum, \& Castro, 2013), and also in language learning (O’Malley \& Chamot, 1990; O’Malley \& Chamot, 1994; Park, 1997; Oxford, 2003; Anderson, 2005; Nisbet, Tindall, \& Arroyo, 2005; Gómez, 2013). In the latter area, students tend to improve their performance even more when their instructors not only teach the target language, but also when they focus on building awareness on the use 
of strategies (O'Malley \& Chamot, 1994; Nunan, 1996; Oxford, 1996a; Kinoshita \& Dokkyo, 2003), so that students can choose the ones that best help them achieve their learning goals (Anderson, 2005). Another relevant aspect to take into account is age since the older people are, the more strategies it seems they tend to develop (Skehan, 1989; Oxford, 1990; Ellis, 1994; Quarles, 1998; Chamot, Kupper, \& Impink-Hernandez, 1998; Yang, 2007) and use them more efficiently (Devlin, 1996; Lee \& Oxford, 2008); this is why age together with learning strategies are considered the two major variables (together with learning strategies) that contribute to the process of second language acquisition (Ellis, 1994).

One of the most prominent researchers on language learning strategies is Rebecca Oxford, who makes a distinction between direct and indirect strategies. Direct strategies are the ones "that directly involve the target language," meaning that they "require mental processing of the language" (Oxford, 1990), while indirect strategies "provide indirect support for language learning through focusing, planning, evaluating, seeking opportunities, controlling anxiety, increasing cooperation and empathy, and other means" (Oxford, 1990). The author identifies six groups within these strategies, namely:

Direct strategies:

1. Cognitive strategies help students to take advantage of the language material in direct ways. Analysis, note-taking, outlining, reasoning, reorganizing information, summarizing, and synthesizing are examples of this type of strategies.

2. Memory-related strategies help learners enter and retrieve new information by creating mental linkages between images and sounds in their memory. These strategies include grouping words, placing new words into context, using imagery, or using physical response, among others.

3. Compensation strategies represent ways in which students deal with gaps in existing knowledge, such as guessing in reading and listening, using synonyms in speaking and writing, and using gestures in speaking.

Indirect strategies:

1. Metacognitive strategies are ways in which students regulate their own learning processes. These involve reflecting, planning, monitoring, and evaluating such processes.

2. Affective strategies are those meant to manage one's emotions, like coping with anxiety, expressing feelings, encouraging and rewarding oneself when performing well, and relaxing.

3. Social strategies help learners tackle language issues by interacting with others through asking questions, cooperating, and empathizing in the group.

Under these premises, Oxford (1989) designed her Strategy Inventory for Language Learning (SILL), featuring 50 quantitative, close-ended questions, aiming to identify the most frequent strategies used by language learners. This questionnaire has been widely used since it was released (Dörnyei, 2005; White, Schramm, \& Chamot, 2007), and it has been translated into several languages (Oxford, 1996b).

Findings about learning strategies used by learners in languages, and other fields, have been reported worldwide. However, there is limited information about the strategies used by older adults, particularly when learning a foreign language. Therefore, this study attempts to determine the learning strategies of a group of elders who took an English course in Cuenca, as well as to ascertain to what extent their language learning strategies are influenced by the socio-demographic variables such as age, knowledge level of English before taking the course, level of education, and occupation before retirement.

\section{METHODOLOGY}

\subsection{Participants and context}

The participants were 66 senior citizens taking a six-month English course at the University of Cuenca, in Ecuador, during the 2014-2015 academic year. This course was taught as part of a research project aiming to assess the effects of learning English upon the cognitive processes of older adults (Estévez et al., 2016). The participants took a placement test before the beginning of the course and then three classes were offered: one called Starter, for those who had never taken English classes before (32 participants); another called Elementary, for those who had some knowledge of English, equivalent to level A1 of the Common European Framework of References for Languages (CEFR) (Council for Cultural Cooperation, 2001) (15 participants); and one called Pre-Intermediate, featuring older adults who could have conversations in English about topics that were familiar or of personal interest, equivalent to level B1 of the CEFR (19 participants).

The average age of this group of older adults was 71.05, of which 5 participants had attended primary school only, 40 secondary school, and 21 college; furthermore, 23 were blue-collar workers before retirement, while 43 were white-collar workers. Table 1 summarizes the participants' socio-demographic profile:

Table 1. Participants' socio-demographic profile.

\begin{tabular}{llcc}
\hline Parameter & Group & $\mathrm{n}$ & $\%$ \\
\hline Age range & 65-70 years & 39 & 59 \\
& 71-80 years & 25 & 38 \\
& 81-85 years & 2 & 3 \\
\hline Gender & Male & 28 & 42 \\
& Female & 38 & 58 \\
\hline School level & Elementary & 5 & 8 \\
& High school & 40 & 60 \\
& University & 21 & 32 \\
\hline Occupation & Blue-collar workers & 23 & 35 \\
before & White-collar & 43 & 65 \\
retirement & workers & & \\
\hline
\end{tabular}

\subsection{Data collection}

The instrument used to determine the learning strategies of the participants was the SILL by Oxford (1990). This 50item questionnaire comprises a set of six sections assessing the frequency with which learners use direct and indirect strategies: memory (9 questions: 1-9), cognitive (14 questions: 10-23), compensation (6 questions: 24-29), metacognitive (9 questions: $30-38$ ), affective (6 questions: 39-44), and social (6 questions: 45-50). The participants responded using a five-point Likert scale, in which 1 means never or almost never true of me, 2 , usually not true of me, 3, somewhat true of me, 4, usually true of me, and 
5, always or almost always true of me. The score obtained establishes the strategies used at high (average score of 3.5 to 5), medium (2.5 to 3.4), and low (2.4 and below) levels. Since this course was taught within the framework of a research project, the participants had already been told at the beginning of the course that, besides usual English tests, a number of surveys and questionnaires would be administered in the classroom at different times. The researchers had the participants engaged in different course activities for several weeks, expecting that their responses to the SILL would resemble the learning experience they were undergoing in that moment. Then, in the fourth month of the course, the questionnaire was applied. This instrument was translated into Spanish by the researchers so that the senior citizens, especially those in the Starter and Elementary groups, could feel confident enough to fully understand the questions and give suitable answers.

\section{ANALYSIS AND RESULTS}

The average response of the participants regarding their most frequently used strategies when learning English is shown in Fig. 1. The results feature the six types of language learning strategies established by Oxford (1990): memory, cognitive, compensation, metacognitive, affective, and social. As can be seen, the participants use memory, cognitive, compensation, affective and social strategies at a medium level, while they are high users of metacognitive strategies. These findings mean that older adults tend to recall information by producing mental pictures and sounds in their memory; they also employ strategies like note-taking, outlining, summarizing, among others, and when they lack knowledge, they compensate for it by guessing, using synonyms or gestures; furthermore, they control the feelings they experience while learning, and they interact with their peers when facing language issues. And, at a greater extent, the participants reflect, plan, monitor and evaluate their learning process when attending the English course.

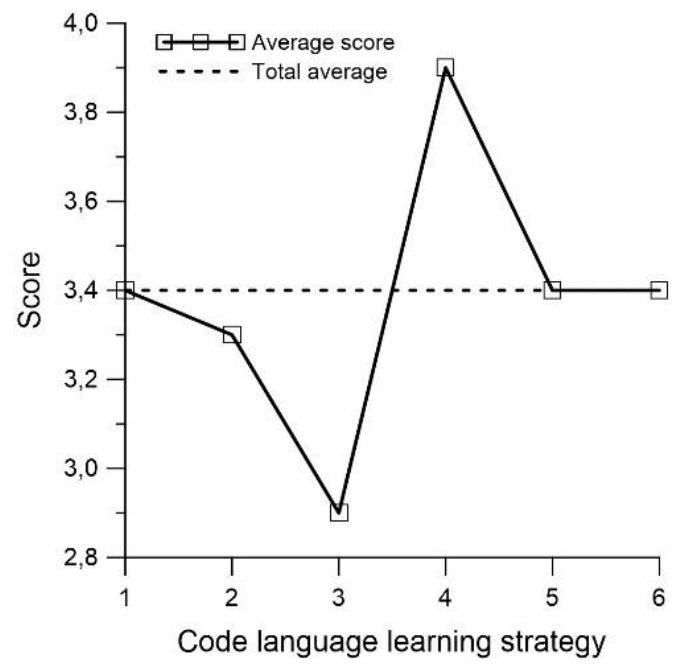

Figure 1. Average score of language learning strategies of older adults. Code language learning strategy: $1=$ Memory-related strategies; $2=$ Cognitive strategies; $3=$
Compensation strategies; 4 = Metacognitive strategies; 5 = Affective strategies; $6=$ Social strategies.

After determining the language learning strategies of the participants, a correlation of such strategies with some sociodemographic variables was carried out. The statistically significant correlations are outlined in the following sections.

Level of English language proficiency and language learning strategies

According to the results of an English placement test, as mentioned before, the participants were assigned to three groups: starter, elementary, and pre-intermediate. Figure 2 shows that the beginners use metacognitive and memory strategies at a high level, and compensation strategies at a medium level. Regarding the elementary learners, the data reveal that their high level of preference is for the cognitive, metacognitive, affective, and social strategies, while they adopt compensation strategies at a medium level. Finally, the pre-intermediate students use metacognitive and social strategies at a high level, while
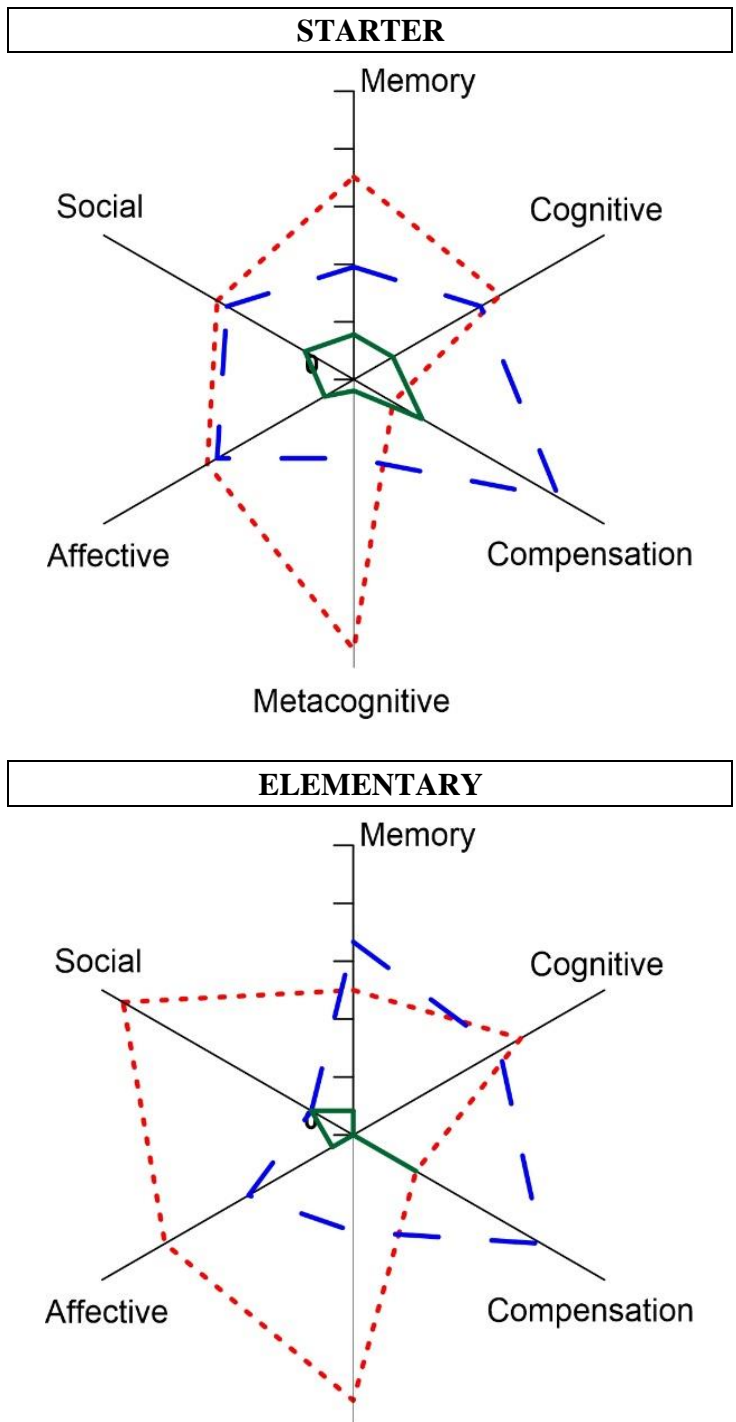

\section{Metacognitive}

Figure 2. Absolute level values of strategy use according to the students' English proficiency, respectively at STARTER, ELEMENTARY and PRE- 
INTERMEDIATE level. Dotted red line: HIGH, large dot blue line: MEDIUM, and full green line: LOW.

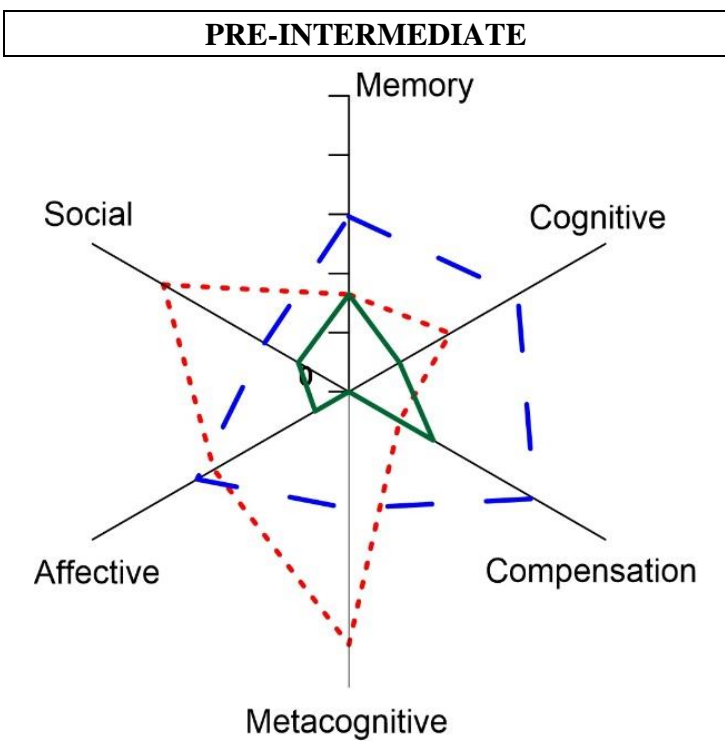

Figure 2. (continued)

using the rest of strategies at a medium level. Besides the above analysis, an ANOVA test ${ }^{1}$ and the Scheffe Test ${ }^{2}$ were applied in order to compare the groups regarding their use of learning strategies. The results, however, do not show statistical differences.

In order to provide more detail about the strategies most and least used by the participants, Table 2 below shows those with a high use (higher than 3.5 points) and those with a minimum use (lower than 2.4 points). As mentioned before, metacognitive strategies (questions 30-38) are the ones the participants use the most and, among them, the strategy the participants predominantly use is I pay attention when someone is speaking English, while the least used strategies belong to the memory and compensation groups.

Table 2. Average of the most and the least used strategies.

\begin{tabular}{|c|c|c|c|}
\hline No & Question & Avg & Level \\
\hline 32 & $\begin{array}{l}\text { I pay attention when someone } \\
\text { is speaking English }\end{array}$ & 4.39 & High \\
\hline 33 & $\begin{array}{l}\text { I try to find out how to be a } \\
\text { better learner of English }\end{array}$ & 4.26 & High \\
\hline 8 & I review English lessons often & 4.11 & High \\
\hline 31 & $\begin{array}{l}\text { I notice my English mistakes } \\
\text { and use that information } \\
\text { to help me do better }\end{array}$ & 4.08 & High \\
\hline 38 & $\begin{array}{l}\text { I think about my progress in } \\
\text { learning English }\end{array}$ & 4.11 & High \\
\hline 5 & $\begin{array}{l}\text { I use rhymes to remember } \\
\text { new English words }\end{array}$ & 2.33 & Low \\
\hline 27 & $\begin{array}{l}\text { I read English without } \\
\text { looking up every new word }\end{array}$ & 2.31 & Low \\
\hline
\end{tabular}

Table 5. Students' T-test distribution between occupation before retirement and language learning strategies (top: AVG_A; bottom: AVG_B).
26 I make up new words if I do Low not know the right ones in English

Age and language learning strategies

To determine the correlation of between age and the average of use of language learning strategies, an analysis based on the Pearson correlation coefficient was applied. The results show that there is not a significant correlation between the above variables. However, when applying the

Table 3. Correlation of age and language learning strategies of the elementary learners $(\mathrm{N}=15)$.

\begin{tabular}{lcc}
\hline Parameter & $\begin{array}{l}\text { Pearson } \\
\text { correlation }\end{array}$ & Sign. (two-tailed) \\
\hline AGE & 1 & \\
AVG_A & -.297 & .283 \\
AVG_B & -.389 & .152 \\
AVG_C & -.431 & .109 \\
AVG_D & -.357 & .192 \\
AVG_E & -.178 & .525 \\
AVG_F & $-.646^{* *}$ & .009
\end{tabular}

same analysis to each of the groups of students, according their level of English, the results show a statistically significant and moderate indirect correlation of the age of the elementary learners and their social learning strategies. This indicates that the older the elementary learners are, the less likely they are to use these strategies to learn English.

Level of education and occupation before retirement and language learning strategies

Table 4 shows the results of an ANOVA test, which reveals that there is a statistically significant difference

Table 4: Correlation of levels of education and language learning strategies of the pre-intermediate learners.

\begin{tabular}{lcll}
\hline Source of variation & Sum squares & DF & $\begin{array}{l}\text { Mean } \\
\text { square }\end{array}$ \\
\hline AVG_A & & & \\
Between groups & 1.313 & 1 & 1.313 \\
Within groups & 4.473 & 17 & 0.263 \\
Corrected total & 5.786 & 18 & \\
F (variance ratio) $=4.991$ & $\mathrm{p}=.039$ & & \\
\hline AVG_B & & & \\
Between groups & 1.718 & 1 & 1.718 \\
Within groups & 4.240 & 17 & 0.249 \\
Corrected total & 5.959 & 18 & \\
F (variance ratio) $=6.888$ & $\mathrm{p}=.018$ & & \\
\hline AVG_C & & & \\
Between groups & 0.948 & 1 & 0.948 \\
Within groups & 3.459 & 17 & 0.203 \\
Corrected total & 4.407 & 18 & \\
F (variance ratio) $=4.660$ & $\mathrm{p}=.045$ & & \\
\hline
\end{tabular}

\footnotetext{
1 Analysis of Variance (ANOVA) is a statistical method to test general rather than specific differences between two or more
} means.
2 The Scheffe Test is a post-hoc test used in analysis of variance
to find out pairs of means that are significant. 


\begin{tabular}{|c|c|c|c|c|}
\hline $\mathrm{AVG}_{\text {_A }}$ & & & $\begin{array}{l}\text { Equal variances } \\
\text { assumed }\end{array}$ & $\begin{array}{l}\text { Equal variances not } \\
\text { assumed }\end{array}$ \\
\hline \multirow{9}{*}{$\begin{array}{l}\text { Levene's test for } \\
\text { equality of variances } \\
\text { T-test for equality of } \\
\text { means }\end{array}$} & $\mathrm{F}$ & & 0.141 & \\
\hline & Sig. & & 0.708 & \\
\hline & $\mathrm{t}$ & & 2.425 & 2.413 \\
\hline & $\mathrm{DF}$ & & 45.726 & 64 \\
\hline & Sig. (2-tailed) & & 0.019 & 0.019 \\
\hline & Mean difference & & 0.4585505 & 0.4585505 \\
\hline & Std. error difference & & 0.1890818 & 0.1900417 \\
\hline & $95 \%$ conf. interval of the & Lower & 0.0778869 & 0.0788985 \\
\hline & difference & Upper & 0.8392140 & 0.8382024 \\
\hline \multicolumn{3}{|l|}{ AVG_B } & $\begin{array}{l}\text { Equal variances } \\
\text { assumed }\end{array}$ & $\begin{array}{l}\text { Equal variances not } \\
\text { assumed }\end{array}$ \\
\hline \multirow{9}{*}{$\begin{array}{l}\text { Levene's test for } \\
\text { equality of variances } \\
\text { T-test for equality of } \\
\text { means }\end{array}$} & $\mathrm{F}$ & & 2.800 & \\
\hline & Sig. & & 0.099 & \\
\hline & $\mathrm{t}$ & & 2.145 & 1.964 \\
\hline & $\mathrm{DF}$ & & 57.038 & 64 \\
\hline & Sig. (2-tailed) & & 0.036 & 0.054 \\
\hline & Mean difference & & 0.3309162 & 0.3309162 \\
\hline & Std. error difference & & 0.1542948 & 0.1684748 \\
\hline & $95 \%$ conf. interval of the & Lower & 0.0219505 & 0.0056509 \\
\hline & difference & Upper & 0.6398818 & 0.6674833 \\
\hline
\end{tabular}

$(p<0.05)$ between the levels of education and the averages of memory-related, compensation, and affective strategies of pre-intermediate learners. It is important to mention that these students attended high school and university; the data indicate that those who went only as far as secondary school seem to use the previously mentioned strategies more often than those who achieved a higher degree of education.

Table 5, on the other hand, indicates the results of a Student's t-test ${ }^{4}$, which show that the averages of memoryrelated and cognitive strategies are correlated to the variable occupation before retirement. The data reveal that those who used to be white-collar workers use those strategies more frequently than those who were blue-collar workers before retirement.

\section{DISCUSSION}

The main target of this study was to determine the learning strategies of a group of elders who were part of an English course in Cuenca, and their possible correlation with the variables age, level of English, level of education and occupation before retirement. Even though this study is exploratory, and therefore could be considered not representative, it may offer useful information on the correlations between the most frequently used strategies of senior citizens and their socio-demographic characteristics, and thus provide research questions for future studies on lifelong learning.

In order to find out the most common strategies used by the group of older adults, the SILL by Oxford was used. The results of this questionnaire reveal that the participants use memory, cognitive, compensation, affective and social strategies at a medium level and metacognitive strategies at a high level. These findings are consistent with those by Quarles (1998), which indicated that in a study conducted over a group of 98 senior citizens, metacognition was their second-most-used strategy, after metamotivation (being aware of their reasons for participating in educational programs). Likewise, Castro (2011) found in a group of 89 university students, majoring engineering and technology, a high use of metacognitive strategies in an EFL context and a medium use of the remaining ones. Similarly, Nisbet, Tindall, \& Arroyo (2005) conducted a study with 168 third-year English majors which indicated that metacognitive strategies were the most frequently used, followed by the social and cognitive ones (high strategy use range), while compensation, affective and memoryrelated strategies featured a medium strategy use range. These studies are mentioned since their participants had already gone through elementary and middle school, meaning that metacognitive strategies are probably mostly handled by individuals with learning experience rather than beginners (Fernández-Castillo, 2015). This assertion is supported by the findings of the two cases previously cited as well as the foregoing study, since all of them included adults who had already attended at least primary school. These outcomes differ, however, from those reported by Chen (2014), which did not find significant differences between the frequency of use of metacognitive strategies of Taiwanese learners in elementary school and university in a study carried out with 1,023 participants from four levels of education.

When analyzing the learning preferences of the present group of older adults and their sociodemographic variables, three correlations were found to be statistically significant:

1. Level of English language proficiency and language learning strategies: the data of this study suggest that the metacognitive strategies are used in all the English levels (starter, elementary, and preintermediate). The participants clearly perform a high use of this strategy. On the other hand, the results of the questionnaire indicate that those

\footnotetext{
4 A test for statistical significance that uses tables of a statistical distribution called Student's t-distribution.
} 
regarded as starters seem to use memory strategies at a high level too, while the same strategy is moderately used by the elementary and preintermediate learners. This might be explained by the language process itself: as participants step forward within this process, the use of memory strategies is gradually replaced by the other strategies (Ellis, 1994; Gavriilidou \& PsaltouJoycey, 2009). These interpretations are supported by similar findings like those of Quarles (1998), Griffiths and Parr (2001), Salem (2006), Salahshour, Sharifi, \& Salahshour (2013), Zarei \& Baharestani (2014), and Al-sohbani (2018) who indicated that memory strategies were used by the individuals in their study far less frequently than were other strategies.

2. Age and language learning strategies: age is another variable that seems to influence language learning strategies among older adults. This study suggests that older learners are not likely to use social strategies. This might be because confidence increases with age, while self-esteem is gained through experience, which is acquired within the learning process (Skehan, 1989). These findings are in line with those of Quarles (1998), Marins (2010), Wu (2011), Sadeghi \& Attar (2013), and Sadeghi \& Khonbi (2012), whose studies showed that when the participants started learning the target language, they tended to use social strategies frequently, but as they got older their preference for that strategy diminished.

3. Level of education and occupation before retirement and language learning strategies: the results of this study show that the participants with higher educational levels (white-collar workers) tend to use memory-related strategies more frequently than those with some high school education or less (bluecollar workers); furthermore, those who attended high school only seem to prefer memory-related, compensation, and affective strategies to a greater extent than those who had higher education. This might mean that memory-related strategies are primarily used by those who engage in learning processes, particularly when attending primary and secondary school, but then that strategy is little by little surpassed by other strategies as the individuals increase their level of education (Oxford, 2003). In the same vein, Quarles (1998), Griffiths \& Parr (2001), Orrego \& Díaz (2010), Castro (2011), Wu (2011), García \& Vivas (2014), and Frankenmolen, Fasotti, Kessels, \& Oosterman (2018) found that memory-related strategies were among the least used by the participants in their studies, most of whom were university students.

\section{CONCLUSIONS}

The results of this study might be helpful to teachers dealing especially with lifelong learning courses. Instructors can help their students by making them aware of different strategies and guiding them in selecting those most useful in achieving specific learning outcomes. In regard to the foregoing study, the strategy most frequently used by the group of older adults taking an English course is the metacognitive strategy; this seems to be the result of their previous (and probably long) formal instruction, which led them to scaffold this strategy. It is worth pointing out that there are no good or bad strategies. Rather, teachers should be aware of how effective the strategies used by their students are in order to suggest other strategies, if applicable, or ways to improve and exploit them accurately. It might also be important to make students aware of their learning styles, so that they can use strategies that better fit such styles.

The main limitation of this study was the small number of participants; therefore, finding significant relationships from the data was difficult. The English courses offered specifically for older adults were the first ones provided by the University of Cuenca at that time. The small number of senior students was probably due to two factors: (a) the publicity of these courses was not advertised enough because of limited financial resources, and (b) since it was the first time this type of courses was offered in the city, the elder community was not aware enough about the benefits an English course might bring them. Therefore, it is suggested further research on how older adults may learn, particularly when attending a foreign language course.

\section{ACKNOWLEDGMENTS}

The authors want to express their deep gratitude to Dr. Alan Blackstock because of his willingness, kindness, and support for the completion of this task.

\section{REFERENCES}

Al-sohbani, Y. (2018). Language learning strategy use by Turkish international school students in Yemen. Journal of Teaching and teacher Education, 6(2), 95-106.

Anderson, N. (2005). Estrategias para el aprendizaje de una lengua extranjera. Káñina, Revista de Artes y Letras, 29(1-2), 171-174.

Barca, A., Peralbo, M., Porto, A. M., Barca, E., Santorum, R., \& Castro, F. V. (2013). Estrategias de aprendizaje, autoconcepto y rendimiento académico en la adolescencia. Revista Galego-Portuguesa de Psicoloxía e Educación, 21, 195-212.

Castro, I. (2011). Language learning strategies for unsuccessful language learners in Ecuador. Master's degree thesis. Guayaquil: Escuela Superior Politéctnica del Litoral.

Chamot, A., Kupper, L., \& Impink-Hernandez, M. (1998). A study of learning strategies in foreign language instruction: Findings of the longitudinal study. McLean, VA: Interstate Research Associates.

Chen, M. (2014). Age differences in the use of language learning strategies. English Language Teaching, 7(2), 144-151. doi:10.5539/elt.v7n2p144

Council for Cultural Cooperation. (2001). Common European framework for languages: Learning, teaching, assessment. Strasbourg, Germany.

Dansereau, (1985). Learning strategy research. In: J.W. Segal, S. F. Chipman, \& R. Glaser (Eds.). Thinking and learning skills (Vol. 1): Relating instruction to research, 
209-240. Florence, KY: Routledge, Taylor \& Francis Group.

Devlin, M. (1996). Older and Wiser? A comparison of the learning and study strategies of mature age and younger teacher education students. Higher Education Research \& Development, 15(1), 51-60.

Dörnyei, Z. (2005). The psychology of the language learner: Individual differences in second language acquisition. Mahwah, NJ: Lawrence Erlbaum Associates.

Ellis, R. (1994). The study of second language acquisition. Oxford: Oxford University Press.

Estévez, F., Webster, F., Mora, F., García, J., Cisneros, V., \& Cevallos, A. (2016). Impacto del aprendizaje del inglés sobre los procesos cognitivos en adultos mayores. Un estudio preliminar en Cuenca. Revista Ecuatoriana de Neurología, 24(1-3), 28-32.

Fernández-Castillo, A. (2015). Estrategias de aprendizaje y adquisición de una segunda lengua. REIDOCREA, 4(48), 391-404.

Frankenmolen, N. L., Fasotti, L., Kessels, R. P., \& Oosterman, J. M. (2018). The influence of cognitive reserve and age on the use of memory strategies. Experimental Aging Research, 44(2), 117-134.

García, M. \& Vivas, A. (2014). Language learning strategies in foreign language learning and proficiency levels by teacher training university students. Revista de Investigación Educativa, 32(2), 363-378.

Gavriilidou, Z. \& Psaltou-Joycey, A. (2009). Language learning strategies: An overview. JAL, 25, 11-25.

Griffiths, C. \& Parr, J. (2001). Language-learning strategies: Theory and perception. ELT Journal, 55(3), 247-254.

Griffiths, C. \& Cansiz, G. (2008). Language learning strategies: An holistic view. Studies in Second Language Learning and Teaching, 5(3), 473-493.

Gómez, B. (2013). Las estrategias de aprendizaje en el aula de lengua extranjera. Bachelor's thesis. Valladolid, Spain: Universidad de Valladolid.

Kinoshita, Y. \& Dokkyo, H. (2003). Integrating language learning strategy instruction into ESL/EFL lessons. TESL Journal, 9(4). Retrieved from http://iteslj.org/Techniques/Kinoshita-Strategy.html

Marins, P. (2010). Estrategias de aprendizaje y desarrollo de la motivación: un estudio empírico con estudiantes de E/LE brasileños. Porta Linguarum, 14, 141-160.

Monereo, C. (Coord.) (1994). Estrategias de enseñanza y aprendizaje. Formación del profesorado y aplicación en la escuela. Barcelona: Graó.

Nisbet, D. L., Tindall, E. R. and Arroyo, A. A. (2005). Language learning strategies and English proficiency of Chinese university students. Foreign Language Annals, 38, 100-107.

Nunan, D. (1996). Learner strategy training in the classroom: An action research study. TESOL Journal, 6(1), 35-41.

O’Malley, M. \& Chamot, A. (1990). Learning strategies in second language acquisition. Cambridge, UK: Cambridge University Press.

O'Malley, J. M. \& Chamot, A. U. (1994). The CALLA handbook: implementing the cognitive academic language learning approach. Reading, MA: AddisonWesley Publishing Company.

Orrego, L. M. \& Díaz, A. E. (2010). Empleo de estrategias de aprendizaje de lenguas extranjeras: inglés y francés. Íkala, 15(24), 105-142.

Oxford, R. L. (1989). Use of language learning strategies: A synthesis of studies with implications for strategy training. System, 17(2), 235-247.

Oxford, R. L. (1990). Language learning strategies: What every teacher should know. New York, NY: Newbury House.

Oxford, R. L. (1996a). Language learning strategies around the World: Cross-cultural perspectives. Manoa, Honolulu: University of Hawaii Press.

Oxford, R. L. (1996b). Employing a questionnaire to assess the use of language learning strategies. Applied Language Learning, 7, 25-45.

Oxford, R. L. (2003). Language learning styles and strategies: An overview. GALA, 1-25.

Park, G. P. (1997). Language learning strategies and English proficiency in Korean universities studies. Foreign Language Annals, 30(2), 211-221.

Pressley, M. \& Associates. (1990). Cognitive strategy instruction that really improves children's academic performance. Cambridge, MA: Brookline Books.

Quarles, H. (1998). Learning strategies preferred by older individuals. $\mathrm{PhD}$ thesis. Bozeman, MT: Montana State University.

Sadeghi, K. \& Attar, M. T. (2013). The relationship between learning strategy use and starting age of learning EFL. Procedia - Social and Behavioral Sciences, 70, 387-396.

Sadeghi, K., \& Khonbi, Z. A. (2012). Learners' starting age of learning EFL and use of language learning strategies. English Language Teaching, 6(1), 28-34.

Salahshour, F., Sharifi, M. \& Salahshour, N. (2013). The relationship between language learning strategy use, language proficiency level and learner gender. Procedia - Social and Behavioral Sciences, 70, 634643.

Salem, N. (2006). The role of motivation, gender, and language learning strategies in EFL proficiency. Beirut, Lebanon: The American University of Beirut.

Skehan, P. (1989). Individual differences in secondlanguage learning. London, UK: Edward Arnold.

White, S., Schramm, K. \& Chamot, A.U. (2007). Research methods in strategy research: Re-examining the toolbox. In: A.D. Cohen and E. Macaro (Eds.). Language learner strategies: Thirty years of practice. Oxford, UK: Oxford University Press, pp. 93-116.

Wu, I. J. (2011). Learning strategies used by international students from Taiwan in a university context: A case study. Master's thesis, California State University, US.

Yang, M. N. (2007). Language learning strategies for junior college students in Taiwan: Investigating ethnicity and proficiency. Asian EFL Journal, 9(2), 63-70. 
J. Mora et al.: Learning strategies of older adults

Zarei, A. \& Baharestani, N. (2014). Language learning strategy use across proficiency levels. i-manager's Journal of English on English Language teaching, 4(4), 27-38.
Zimmerman, B. J. \& Pons, M. M. (1986). Development of a structured interview for assessing student use of self-regulated learning strategies. American Educational Research Journal, 23, 614-628. 